\title{
Some Physiological Parameters as Screening Tools for Drought Tolerance in Bread Wheat Lines (Triticum aestivam L.)
}

\author{
A.A.S. Ahmed ${ }^{1}$, R. Uptmoor ${ }^{2}$, M.A. El-Morshidy ${ }^{3}$, K.A. Kheiralla ${ }^{3}$, M.A. Ali $^{4}$, Naheif E.M. Mohamed ${ }^{1, *}$ \\ ${ }^{1}$ Dep. of Agronomy, Faculty of Agriculture, Sohag University, Egypt \\ ${ }^{2}$ Institute of Biological Production Systems, Hannover University, Germany \\ ${ }^{3}$ Dep. of Agronomy, Faculty of Agriculture, Assiut University, Egypt \\ ${ }^{4}$ Dep. of Agronomy, Faculty of Agriculture, South Valley University, Egypt \\ *Corresponding author: naheif@yahoo.com
}

Received October 22, 2013; Revised Noverber 23, 2013; Accepted May 06, 2014

\begin{abstract}
Two greenhouse experiments were carried out at the Institute of Biological Production Systems, Leibniz Universität Hannover, Germany during 2008/2009 and 2009/2010 growing seasons to study the influence of the osmotic adjustment (OA) capacity, relative water content (RWC) and specific leaf area (SLA) on tolerance to drought in 22 breeding lines, two parents and tolerant cultivar (Sahel 1) of bread wheat (Triticum aestivam L.) under drought conditions. Differences were seen in of the OA, RWC and SLA of the different genotypes. Mean over all of OA, RWC and SLA for breeding lines were $-0.51 \mathrm{Mpa}, 83.28 \%$ and $116.56 \mathrm{~cm}^{2} \mathrm{~g}-1$, respectively. Four of the breeding lines showed the greatest osmotic adjustment capacities, high RWC and good SLA values under drought stress conditions better than the tolerant cultivar. The heritability of OA, RWC and SLA was 0.56, 0.49 and 0.88, respectively. The results indicated that osmotic adjustment, as well as RWC and SLA could be used as screening tools for drought resistant bread wheat genotypes in the greenhouse. This study also demonstrated the appropriate greenhouse screening methodology in this regard.
\end{abstract}

Keywords: wheat, drought, osmotic adjustment, heritability

Cite This Article: A.A.S. Ahmed, R. Uptmoor, M.A. El-Morshidy, K.A. Kheiralla, M.A. Ali, and Naheif E.M. Mohamed, "Some Physiological Parameters as Screening Tools for Drought Tolerance in Bread Wheat Lines (Triticum aestivam L.).” World Journal of Agricultural Research, vol. 2, no. 3 (2014): 109-114. doi: 10.12691/wjar-2-3-4.

\section{Introduction}

Wheat (Triticum aestivum L.) is a staple food for more than $35 \%$ of the world population and it is also the first grain crop in Egypt. Drought is the most important limiting factor for crop production and it is becoming an increasingly severe problem in many regions of the world. In addition to the complexity of drought itself [27,28].

The objective in many breeding programs is to develop cultivars tolerant to drought stress but success has been limited. Genetic improvement of stress tolerance in crop plants requires identification of relevant physiological stress tolerance mechanisms as selection criteria [16] and testing to verify the value of such criteria for improvement of stress tolerance. Osmotic adjustment (OA) is generally considered an important component of drought resistance [15]. Osmotic adjustment (OA) strongly depends on the rate of plant water stress. OA requires time, and fast reduction in plant water status does not allow time for adjustment. This is very significant when genotypes are compared for their OA capacity. However, the importance of the time and the rate of stress for the development of
OA imply that OA may not be a very effective mechanism of drought resistance under conditions where the development of drought is by nature very rapid, such on very light tropical or sandy soils of very low water holding capacity [2]. It was recently shown that a population issued from an inland desertic area displayed a higher ability for $\mathrm{OA}$ in drought conditions than a population originating from a salt-affected coastal site [24]. These contrasting populations provide interesting material with which to (i) quantify the relative contribution of various osmolytes to $\mathrm{OA}$ and (ii) to determine the importance of $\mathrm{OA}$ in the adaptative response of Atriplex halimus to water stress.

Leaf relative water content (RWC) was a better indicator of water status than was water potential [18]. Measurements of relative water content (RWC) in leaf tissues are commonly used to assess the water status of plants [37]. Ref. [26] stated that RWC of bean leaves under drought stress significantly was lesser than control. Ref. [14] subjected bean plant to drought stress and after 10, 14 and 18 days after irrigation was with holded, they evaluated RWC of stem and found RWC was significantly lower comparing with control plants. Ref. [9] applied antitranspirant maters on two Sesame cultivars named 
Gize 32 and Shanavil 3 and observed that this matters by preventing water transpiration from leaves, led to increase in RWC in these cultivars. Specific leaf area (SLA), an indictor of leaf thickness, has often been observed to be reduced under drought conditions [21].

In the present work the mechanisms involved in the response to drought were investigated in 22 wheat Lines with contrasting drought tolerance capacities, in order to study the relationship between the physiological basis of drought response and plant stress tolerance.

\section{Material and Methods}

The present investigation was carried out in the greenhouse during 2008/2009 and 2009/2010 at the Institute of Biological Production Systems, Leibniz Universität Hannover, Germany. The breeding materials used in this study consisted of all F5 families selected in F4 on the basis of high yield under drought conditions, as well as parents and the tolerant cultivar (Sahel 1). The total number of evaluated families was 22 families. The used genetic material:

Table 1. The pedigree and origin of the two parents and the tolerant cultivar (Sahel 1)

\begin{tabular}{ccc}
\hline Parental name & Pedigree & Origin \\
Sids 4 (P1) & May'S'/Mon'S'//CMH74A.592/3/Giza 157*2 & Egypt \\
Tokwie (P2) & ----- & South Africa \\
Sahel 1 & NS 732/PIMA//Veery'S' & ICARDA
\end{tabular}

Laboratory procedures:

Two experiments were carried out during 2007/2008 and 2008/2009 seasons. Polyvinyl chloride columns of $12.5 \mathrm{~cm}$ inner diameter were used and the length of the columns was $50 \mathrm{~cm}$ in the two experiments. The substrate for growing the plants was homogenized loamy soil, which was dried in the greenhouse for one month before starting the experiments. While filling the columns, soil samples were taken to determine the initial soil water content. Soil water holding capacity (SWHC) was measured by subtracting the weight of columns filled with dry soil and the weight of columns saturated with water after allowing the exceeding water to drain until there was no change in the weight.

The experiment was designed as RCBD with four replicates in north-south direction, and genotypes were completely randomized within the plots. Two seeds were sown in the middle of every column. After germination, one seedling was removed. Plants were kept well watered at $80 \%$ water holding capacity (WHC), Columns were weighed and plants were topped up every third day to reach required SWHC and the drought stress cycle was started four weeks after sowing and the duration of the stress cycle was about 4 weeks. Fertilizer was applied to the optimum dosage and diseases and pests were controlled using appropriate pesticides.

The following measurements were recorded: -

- Physiological traits.

1. Relative leaf water content (\%) (RWC): was measured at the beginning of the stress cycle and at the end of stress cycle on leaf cuttings, a small part of leaf area of the main tiller and the first biggest other tiller were cut and RWC was calculated using the following equation:

$\mathrm{RWC}=(\mathrm{FW}-\mathrm{DW}) /(\mathrm{TW}-\mathrm{DW}) \times 100$

where FW and DW are fresh weight and dry weight of the leaf and TW is the turgor weight of the leaf after submergence of leaf samples in distilled water for $24 \mathrm{~h}$.

2. Osmotic potential ( $\Psi s)$ : was measured at the beginning of the stress cycle and after the stress cycle on leaf cuttings, a small part of leaf area of the main tiller and the first biggest other tiller were cut and stored to measure osmotic potential by using the psych- rometric method and Wescor C-52 sample chambers (Wescor Inc., Logan, USA). $\Psi$ s, cd was corrected for relative leaf water content. Osmotic adjustment (Mpa), OA was estimated as follows:

$\mathrm{OA}=\Psi_{\mathrm{s}, \mathrm{cd}} \times \mathrm{RWC}_{\mathrm{cd}} \Psi_{\mathrm{s} \text {, ww }} \times \mathrm{RWC}_{\mathrm{ww}}$ where $\Psi_{\mathrm{s}, \mathrm{cd}}$ and $\mathrm{RWC}_{\mathrm{cd}}$ are $\Psi_{\mathrm{s}}$ and RWC under drought stress conditions, and $\Psi_{s, w w}$ and $\mathrm{RWC}_{\mathrm{ww}}$ are $\Psi_{\mathrm{s}}$ and $\mathrm{RWC}$ under well watered conditions.

3. Specific leaf area $\left(\mathrm{cm}^{2} \mathrm{~g}-1\right)$ : was measured after the stress cycle for all leaves and it will be calculated by:

The ratio of leaf area to leaf dry mass $\left(\mathrm{cm}^{2} \mathrm{~g}-1\right)$.

Statistical procedures:

1. Analysis of variance for randomized complete block design was carried out according to Snedecor and Cochran (1980).

2. The genotypic variance $\sigma 2 \mathrm{~g}=\mathrm{M} 2-\mathrm{M} 1 / \mathrm{r}$

3. The phenotypic variance $\sigma 2 \mathrm{p}=\sigma 2 \mathrm{~g}+\sigma 2 \mathrm{e}$

4. The genotypic (G.C.V\%) and phenotypic (P.C.V\%) coefficients of variability were calculated as $\sigma g / \bar{x}$ and $\sigma p$ $/ \bar{x}$, respectively.

5. Heritability in the broad sense $(\mathrm{H})$ was estimated as the ratio of genotypic $(\sigma 2 g)$ to the phenotypic $(\sigma 2 g+\sigma 2 e)$ variance according to Walker (1960).

Table 2. The analysis of variance and expected means of squares

\begin{tabular}{cccc} 
Source of variance & D.F & M. S & E. M. S \\
\hline Replication & $\mathrm{r}-1$ & $\mathrm{M}_{3}$ & $\sigma^{2} \mathrm{e}+\mathrm{g} \sigma^{2} \mathrm{r}$ \\
Genotypes & $\mathrm{g}-1$ & $\mathrm{M}_{2}$ & $\sigma^{2} \mathrm{e}+\mathrm{r} \sigma^{2} \mathrm{~g}$ \\
Error & $(\mathrm{r}-1)(\mathrm{g}-1)$ & $\mathrm{M}_{1}$ & $\sigma^{2} \mathrm{e}$ \\
\hline
\end{tabular}

6. Mean comparisons were calculated by using revised L.S.D where, L.S.D = least significant difference, and was calculated as:

R L S D $\alpha=(\mathrm{t}-) \alpha * \sqrt{ }(2 \mathrm{MSE} / \mathrm{r})$ (El Rawi and Khalafalla 1980)

Where $\mathrm{t}$ - is the $\mathrm{t}$ value from "minimum-average-risk ttable" at F-value of treatments, treatment $\mathrm{df}$ and experimental error df.

\section{Results and Discussion}

The analysis of variance (Table 3) revealed highly significant differences among the families selected of population I on independent culling levels basis in all physiological traits, i.e., relative leaf water content under well-watered $\left(\mathrm{RWC}_{\mathrm{ww}}\right)$ and relative water content under drought stress conditions $\left(\mathrm{RWC}_{\mathrm{cd}}\right)$, specific leaf area under drought stress $\left(\mathrm{SLA}_{\mathrm{cd}}\right)$ and osmotic adjustment (OA) in the two years. 
Table 3. Analysis of variance

\begin{tabular}{|c|c|c|c|c|c|c|}
\hline \multirow{2}{*}{ Years } & \multirow{2}{*}{ S.O.V } & \multirow{2}{*}{ d.f } & \multicolumn{4}{|c|}{ Mean Squares } \\
\hline & & & $\mathrm{RWC}_{\mathrm{ww}}$ & $\mathrm{RWC}_{\mathrm{cd}}$ & $\mathrm{SLA}_{\mathrm{cd}}$ & $\mathrm{OA}$ \\
\hline \multirow{3}{*}{ 옹 } & Reps & 3 & 18.21 & 8.95 & 85.14 & 0.01 \\
\hline & Families & 24 & $13.46^{* *}$ & $13.96 * *$ & $1892.79 * *$ & $0.04^{* *}$ \\
\hline & Error & 72 & 2.99 & 2.83 & 36.46 & 0.006 \\
\hline \multirow{3}{*}{ 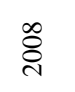 } & Reps & 3 & 3.85 & 1.17 & 70.38 & 0.003 \\
\hline & Families & 24 & $8.82 * *$ & $13.73 * *$ & $1116.70^{* *}$ & $0.05^{* *}$ \\
\hline & Error & 72 & 3.31 & 2.89 & 52.48 & 0.009 \\
\hline
\end{tabular}

The combined analysis over two years (Table 4) revealed highly significant differences among families and years for the above mentioned traits in the two populations. While, families $\mathrm{x}$ years interaction were highly significant for $\mathrm{SLA}_{\mathrm{cd}}$ and $\mathrm{OA}$ and non significant for $\mathrm{RWC}_{\mathrm{ww}}$ and $\mathrm{RWC}_{\mathrm{cd}}$ in the two populations.

Table 4. The combined analysis of variance over the two years

$\begin{array}{cccccc}\text { S.O.V } & \text { d.f } & \text { RWC }_{\mathrm{ww}} & \mathrm{RWC}_{\mathrm{cd}} & \mathrm{SLA}_{\mathrm{cd}} & \mathrm{OA} \\ \text { Year } & 1 & 280.54^{* *} & 116.60^{* *} & 17196.6^{* *} & 0.32^{* *} \\ \text { Rep/Year } & 6 & 6.32 & 3.96 & 67.00 & 0.01 \\ \text { Families } & 24 & 21.36^{* *} & 24.45^{* *} & 2765.88^{* *} & 0.06^{* *} \\ \text { F x Y } & 24 & 0.93 & 3.24 & 243.60^{* *} & 0.04^{* *}\end{array}$

The range and the mean values of the four studied traits within and across the two years are presented in Table 5 and Figure 1. The results showed that average of $\mathrm{RWC}_{\mathrm{ww}}$ was $88.23 \%$ with a range from 84.35 to $91.99 \%$ in the first season and in the second season, the average was $85.82 \%$ with a range from 82.56 to $89.10 \%$. However, mean across years of $\mathrm{RWC}_{\mathrm{ww}}$ was $87.03 \%$ with a range from 83.46 to $90.54 \%$. Moreover, the results showed that six families, i.e., no. 6, 22, 33, 38, 43 and 45 and two families, i.e., no. 33 and 38 significantly exceeded the best parent in the first and the second seasons, respectively. While, ten families, i.e., no. $6,13,22,23,25,33,36,38,43$ and 45 and six families, i.e., no. 6, 22, 33, 36, 38 and 45 were significantly higher than the check in the first and the second seasons, respectively.

Table 5. The range and the mean values for the physiological traits within and across years

\begin{tabular}{cccc} 
Trait & Year & Range & Means \pm S.E \\
& 2007 & $84.35-91.99$ & $88.23 \pm 0.25$ \\
RWCww (\%) & 2008 & $82.56-89.10$ & $85.82 \pm 0.22$ \\
& Mean & $83.46-90.54$ & $87.03 \pm 0.18$ \\
\multirow{2}{*}{ RWCcd (\%) } & 2007 & $80.41-87.30$ & $84.04 \pm 0.24$ \\
& 2008 & $79.17-86.35$ & $82.51 \pm 0.23$ \\
SLAcd (Cm ${ }^{2}$ kg- $\left.^{1}\right)$ & Mean & $80.33-86.83$ & $83.28 \pm 0.18$ \\
& 2007 & $81.33-165.32$ & $125.77 \pm 2.21$ \\
& Mean & $86.51-14.54$ & $107.36 \pm 1.76$ \\
OA (Mpa) & 2007 & $-0.36--0.79$ & $-0.56 \pm 0.01$ \\
& 2008 & $-0.23--0.68$ & $-0.47 \pm 0.01$ \\
& Mean & $-0.37--0.68$ & $-0.51 \pm 0.01$
\end{tabular}

The average $\mathrm{RWC}_{\mathrm{cd}}$ in Table 5 and Figure 2 was $84.04 \%$ with a range from 80.41 to $87.30 \%$ and from 79.17 to $86.35 \%$ with an average $82.51 \%$ in the first and second season, respectively. Mean over all for $\mathrm{RWC}_{\mathrm{cd}}$ was $83.28 \%$ with a range from 80.33 to $86.83 \%$. Three families (no. 22, 33 and 36) and two families (no. 22 and 33) were significantly higher than the best parent in the first and the second seasons, respectively. Meanwhile, three families (no. 22, 33 and 36) and four families (no. 22, 25, 33 and 36) surpassed the check (Sahel 1) in the first and the second seasons, respectively (Table 6). These results are in agreement with those obtained by, [35,20], [32,33]. Ref. [12] cleared that the range of leaf relative water content varied from 50.03 for ND66 to $72.02 \%$ for L31under terminal water-stress condition.
Mean SLA $_{\text {cd }}$ presented in Table 5 and Figure 3 was $125.77 \mathrm{~cm}^{2} \mathrm{~g}^{-1}$ with a range from 81.33 to $165.32 \mathrm{~m}^{2} \mathrm{~kg}-1$ and from 85.15 to $144.58 \mathrm{~cm}^{2} \mathrm{~g}^{-1}$ with an average 107.36 in the first and second seasons, respectively. However, mean across years of SLA $_{c d}$ was $116.56 \mathrm{~m}^{2} \mathrm{~kg}-1$ with a range from 86.51 to $154.95 \mathrm{~cm}^{2} \mathrm{~g}^{-1}$. Twelve families, i.e., no. $6,19,22,23,24,25,26,28,33,38,45$ and 46 in the two years were significantly higher than the best parent. While, twelve families, i.e., no. 6, 19, 22, 23, 24, 25, 26 , 28, 33, 38, 45 and 46 in the first season and all breeding lines except (no. 13, 37, 39 and 43) in the second season surpassed the check (Table 7).

Table 6. The average of relative leaf water content under normal (RWCWw) and drought (RWCcd) conditions across the two years

\begin{tabular}{|c|c|c|c|c|c|c|}
\hline \multirow[b]{2}{*}{$\begin{array}{l}\text { Selected } \\
\text { families }\end{array}$} & \multicolumn{3}{|c|}{$\mathrm{RWC}_{\mathrm{ww}}$} & \multicolumn{3}{|c|}{$\mathrm{RWC}_{\mathrm{cd}}$} \\
\hline & Year 1 & Year 2 & $\begin{array}{c}\text { Mean } \\
\text { over } \\
\text { all }\end{array}$ & Year 1 & Year 2 & $\begin{array}{c}\text { Mean } \\
\text { over } \\
\text { all }\end{array}$ \\
\hline 1 & 87.50 & 85.36 & 86.43 & 85.06 & 83.57 & 84.31 \\
\hline 6 & 90.43 & 87.20 & 88.81 & 82.51 & 81.19 & 81.85 \\
\hline 13 & 89.35 & 86.19 & 87.77 & 85.90 & 82.48 & 84.19 \\
\hline 19 & 87.99 & 84.55 & 86.27 & 84.90 & 84.19 & 84.54 \\
\hline 22 & 89.85 & 87.20 & 88.52 & 86.69 & 85.37 & 86.03 \\
\hline 23 & 88.83 & 86.81 & 87.82 & 83.18 & 82.12 & 82.65 \\
\hline 24 & 86.08 & 84.79 & 85.44 & 80.41 & 82.21 & 81.31 \\
\hline 25 & 88.83 & 86.21 & 87.52 & 85.69 & 84.59 & 85.14 \\
\hline 26 & 85.54 & 83.24 & 84.39 & 82.68 & 81.34 & 82.01 \\
\hline 28 & 86.44 & 85.34 & 85.89 & 81.48 & 79.17 & 80.33 \\
\hline 33 & 91.99 & 89.10 & 90.54 & 87.30 & 86.35 & 86.83 \\
\hline 36 & 89.44 & 87.30 & 88.37 & 87.09 & 84.74 & 85.92 \\
\hline 37 & 87.59 & 86.03 & 86.81 & 84.55 & 83.77 & 84.16 \\
\hline 38 & 90.43 & 87.55 & 88.99 & 84.91 & 82.42 & 83.66 \\
\hline 39 & 88.38 & 86.31 & 87.34 & 84.84 & 83.33 & 84.09 \\
\hline 42 & 87.28 & 85.00 & 86.14 & 83.11 & 82.49 & 82.80 \\
\hline 43 & 89.68 & 86.44 & 88.06 & 85.96 & 81.56 & 83.76 \\
\hline 45 & 90.94 & 87.18 & 89.06 & 83.99 & 81.54 & 82.76 \\
\hline 46 & 87.45 & 85.74 & 86.59 & 82.79 & 83.60 & 83.20 \\
\hline 48 & 86.07 & 83.33 & 84.70 & 81.35 & 79.87 & 80.61 \\
\hline 55 & 86.64 & 84.66 & 85.65 & 82.49 & 79.43 & 80.96 \\
\hline 62 & 84.35 & 82.56 & 83.46 & 82.02 & 79.96 & 80.99 \\
\hline Average & 88.23 & 85.82 & 87.03 & 84.04 & 82.51 & 83.28 \\
\hline $\mathrm{P}_{1}$ & 87.10 & 84.47 & 86.04 & 83.02 & 82.47 & 82.74 \\
\hline $\mathrm{P}_{2}$ & 86.34 & 83.95 & 85.15 & 83.65 & 81.14 & 82.40 \\
\hline Sahel 1 & 86.24 & 84.02 & 85.38 & 83.62 & 82.12 & 83.37 \\
\hline $\mathrm{RLSD}_{0.05}$ & 2.51 & 3.02 & -- & 2.44 & 2.46 & -- \\
\hline $\mathrm{RLSD}_{0.01}$ & 3.31 & 4.14 & -- & 3.22 & 3.26 & -- \\
\hline
\end{tabular}

RWC (Well watered)

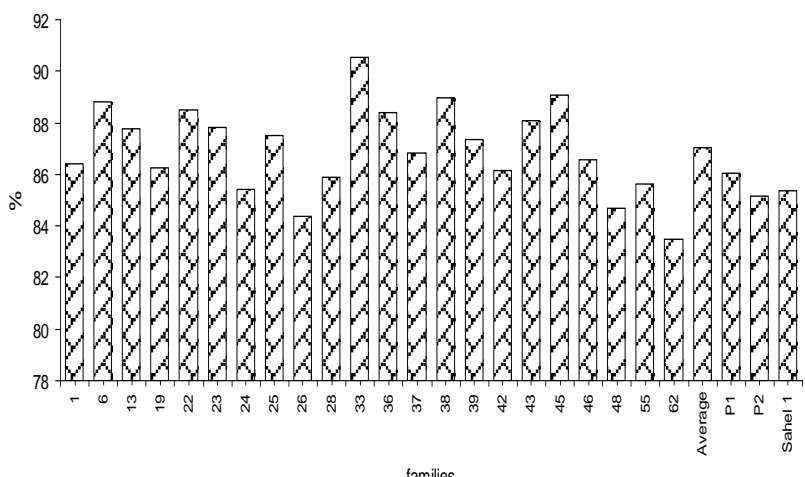

Figure 1. relative leaf water content under normal $\left(\mathrm{RWC}_{\mathrm{ww}}\right)$ and Drought condition $\left(\mathrm{RWC}_{\mathrm{cd}}\right)$ of independent culling levels $\mathrm{f}_{5}$ families of population I 


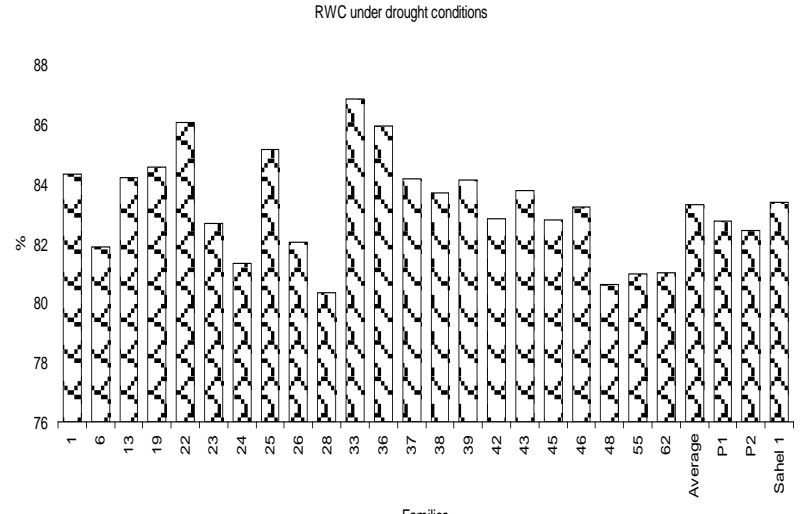

Figure 2. relative leaf water content under normal $\left(\mathrm{RWC}_{\mathrm{ww}}\right)$ and Drought condition $\left(\mathrm{RWC}_{\mathrm{cd}}\right)$ of independent culling levels $\mathrm{f}_{5}$ families of population I

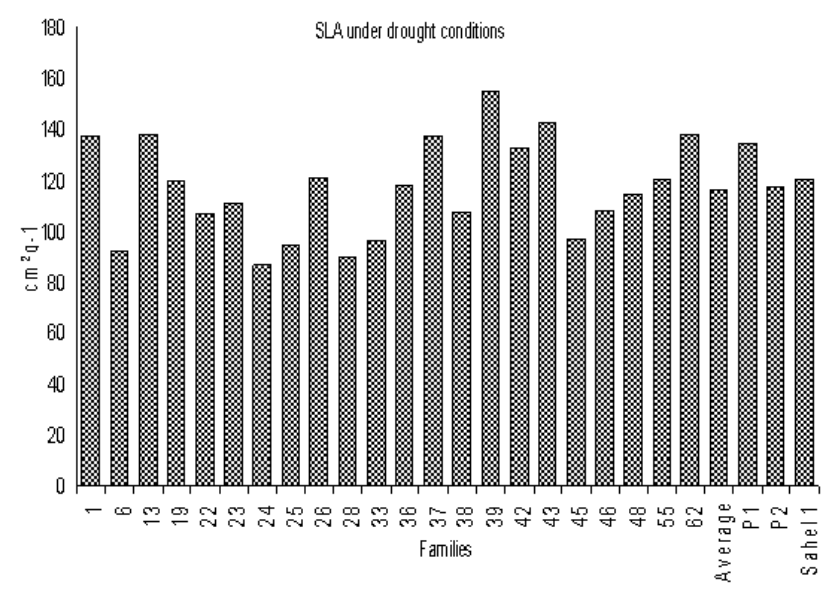

Figure 3. The average of specific leaf area under drought conditions $\left(\mathrm{SLA}_{\mathrm{cd}}\right)$ and Osmotic adjustment $(\mathrm{OA})$ of independent culling levels $\mathrm{f}_{5}$ families of population I
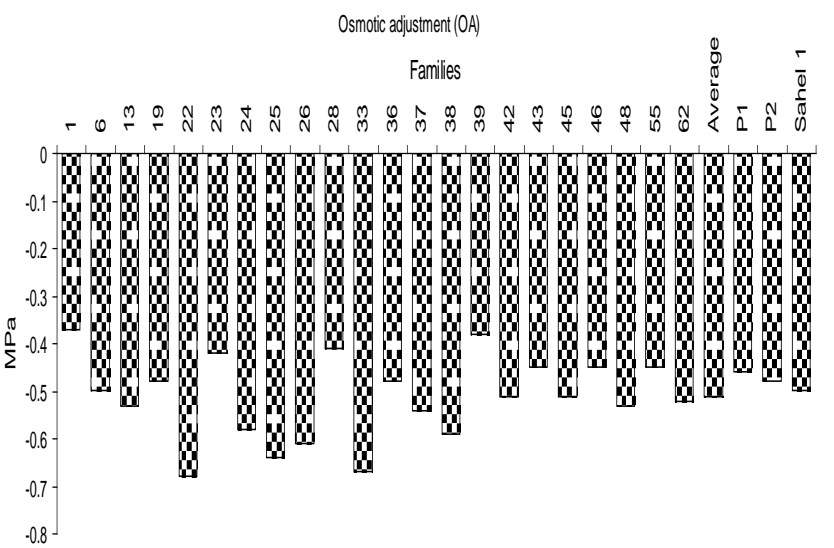

Figure 4. The average of specific leaf area under drought conditions $\left(\mathrm{SLA}_{\mathrm{cd}}\right)$ and Osmotic adjustment (OA) of independent culling levels $\mathrm{f}_{5}$ families of population I

The average of osmotic adjustment (OA) was -0.56 Mpa with a range from -0.36 to $-0.79 \mathrm{Mpa}$ and from 0.23 to $-0.68 \mathrm{Mpa}$ with an average $-0.47 \mathrm{Mpa}$ in the first and second seasons, respectively. Moreover, mean over all was $-0.51 \mathrm{Mpa}$ with a range from -0.37 to $-0.68 \mathrm{Mpa}$ (Table 5 and Figure 4). Moreover, five families (no. 22, 25, 26, 33 and 48) and three families (no. 22, 33 and 38) significantly exceeded the best parent in the first and the second seasons, respectively. While, five families, i.e., no. 22, 25, 26, 33 and 48 and four families, i.e., no. 19, 22, 33 and 38 surpassed the best parent in the first and the second seasons, respectively (Table 7). The wide range of variability among genotypes also indicates the suitability of $\mathrm{OA}$ as selection tool for breeders under water deficit environments. These results were in agreement with these obtained by [3,16,19,20,22,23]. Also, Ref. [26] showed that Tullio, the drought susceptible Italian genotype, had an osmotic adjustment of $-0.63 \mathrm{MPa}$, four times greater than in Pandas, though this drought resistant cultivar showed a similar content in osmotically active substances.

Table 7. The average of specific leaf area under drought conditions (SLAcd) and osmotic adjustment (OA) across the two years

\begin{tabular}{|c|c|c|c|c|c|c|}
\hline \multirow[b]{2}{*}{$\begin{array}{l}\text { Selected } \\
\text { families }\end{array}$} & \multicolumn{3}{|c|}{$\operatorname{SLA}_{\mathrm{cd}}$} & \multicolumn{3}{|c|}{ OA } \\
\hline & $\begin{array}{c}\text { Year } \\
1\end{array}$ & $\begin{array}{c}\text { Year } \\
2\end{array}$ & $\begin{array}{c}\text { Mean } \\
\text { over all }\end{array}$ & Year1 & $\begin{array}{c}\text { Year } \\
2\end{array}$ & $\begin{array}{c}\text { Mean } \\
\text { over all }\end{array}$ \\
\hline 1 & 153.83 & 121.38 & 137.60 & -0.40 & -0.33 & -0.37 \\
\hline 6 & 99.03 & 85.15 & 92.09 & -0.59 & -0.40 & -0.50 \\
\hline 13 & 148.85 & 127.16 & 138.00 & -0.55 & -0.51 & -0.53 \\
\hline 19 & 127.48 & 112.22 & 119.85 & -0.36 & -0.59 & -0.48 \\
\hline 22 & 116.72 & 97.46 & 107.09 & -0.67 & -0.68 & -0.68 \\
\hline 23 & 119.25 & 102.41 & 110.83 & -0.53 & -0.31 & -0.42 \\
\hline 24 & 81.33 & 91.69 & 86.51 & -0.61 & -0.54 & -0.58 \\
\hline 25 & 101.81 & 87.51 & 94.66 & -0.79 & -0.49 & -0.64 \\
\hline 26 & 123.78 & 117.98 & 120.88 & -0.65 & -0.57 & -0.61 \\
\hline 28 & 88.77 & 90.89 & 89.83 & -0.51 & -0.31 & -0.41 \\
\hline 33 & 106.52 & 85.93 & 96.22 & -0.72 & -0.63 & -0.67 \\
\hline 36 & 135.43 & 100.62 & 118.02 & -0.51 & -0.45 & -0.48 \\
\hline 37 & 142.71 & 131.76 & 137.24 & -0.58 & -0.50 & -0.54 \\
\hline 38 & 115.66 & 99.70 & 107.68 & -0.57 & -0.61 & -0.59 \\
\hline 39 & 165.32 & 144.58 & 154.95 & -0.54 & -0.23 & -0.38 \\
\hline 42 & 146.30 & 118.55 & 132.43 & -0.59 & -0.44 & -0.51 \\
\hline 43 & 148.89 & 135.83 & 142.36 & -0.38 & -0.53 & -0.45 \\
\hline 45 & 106.34 & 88.08 & 97.21 & -0.52 & -0.50 & -0.51 \\
\hline 46 & 118.95 & 97.28 & 108.11 & -0.43 & -0.46 & -0.45 \\
\hline 48 & 133.08 & 96.13 & 114.60 & -0.68 & -0.39 & -0.53 \\
\hline 55 & 132.11 & 108.96 & 120.53 & -0.56 & -0.33 & -0.45 \\
\hline 62 & 154.68 & 120.70 & 137.69 & -0.51 & -0.54 & -0.52 \\
\hline Average & 125.77 & 107.36 & 116.56 & -0.56 & -0.47 & -0.51 \\
\hline $\mathrm{P}_{1}$ & 149.60 & 119.70 & 134.70 & -0.44 & -0.48 & -0.46 \\
\hline $\mathrm{P}_{2}$ & 126.00 & 108.70 & 117.30 & -0.53 & -0.43 & -0.48 \\
\hline Sahel 1 & 126.00 & 114.50 & 120.30 & -0.54 & -0.46 & -0.50 \\
\hline $\mathrm{RLSD}_{0.05}$ & 4.47 & 9.48 & -- & 0.11 & 0.13 & -- \\
\hline $\operatorname{RLSD}_{0.01}$ & 9.78 & 12.47 & -- & 0.14 & 0.17 & -- \\
\hline
\end{tabular}

The phenotypic (P.C.V.\%) and genotypic (G.C.V.\%) coefficients of variation and heritability $\left(h_{2}\right)$ estimates for all studied traits in the first (2007) and the second (2008) seasons are presented in Table (8). The results showed that the phenotypic and genotypic coefficient of variation were (2.68 and $1.83 \%$ ) and (2.52 and $1.37 \%)$ for $\mathrm{RWC}_{\mathrm{ww}}$, (2.82 and $1.98 \%$ ) and (2.87 and $2.00 \%$ ) for $\mathrm{RWC}_{\mathrm{cd}}$, (17.79 and $17.13 \%)$ and (16.62 and $15.19 \%$ ) for SLA $_{c d}$ and (25.26 and $19.62 \%)$ and (27.20 and $19.85 \%)$ for OA in the first and second seasons, respectively.

Table 8. Phenotypic coefficient of variation (PCV\%), genotypic coefficient of variation (GCV\%) and broad sense heritabilities (h2) for all studied traits

$\begin{array}{ccccc}\text { Traits } & \text { Year } & \text { PCV\% } & \text { GCV\% } & h^{2} \\ \text { RWC }_{w w} & 2007 & 2.68 & 1.83 & 46.68 \\ & 2008 & 2.52 & 1.37 & 29.39 \\ \text { RWC }_{c d} & 2007 & 2.82 & 1.98 & 49.58 \\ & 2008 & 2.87 & 2.00 & 48.39 \\ \text { SLA }_{c d} & 2007 & 17.79 & 17.13 & 92.72 \\ & 2008 & 16.62 & 15.19 & 83.52 \\ \text { OA } & 2007 & 25.62 & 19.62 & 58.62 \\ & 2008 & 27.20 & 19.85 & 53.25\end{array}$

The broad sense heritabilities (Table 8) were (46.68 and 29.39\%) for $\mathrm{RWC}_{\mathrm{ww}}$, (49.58 and $48.39 \%$ ) for $\mathrm{RWC}_{\mathrm{cd}}$, (92.72 and $83.52 \%)$ for SLAcd and (58.62 and $53.25 \%$ ) for $\mathrm{OA}$ in the first and second seasons, respectively. The high heritability estimates obtained for both $\mathrm{SLA}_{\mathrm{cd}}$ and 
OA provide evidence for the effectiveness of selection for both characters in improving drought tolerance. These results are in accordance with those obtained by $[5,10,11,34,35]$.

\section{Conclusions}

Survival and productivity of crop plants exposed to environmental stresses are dependent on their ability to develop adaptive mechanisms to avoid tolerate stress [1]. This study was following to find characters of resistant under drought stress and the results showed that osmotic adjustment, Relative water content and Specific leaf area made difference between genotypes. Thus, this attributes can be used as screening tool for drought tolerance in Wheat. They lend full support to results presented by $[16,20,22]$ showing that wheat lines can differ consistently for OA. It is therefore concluded that OA can be an important component of drought resistance in wheat within a relevant environmental context and by [30] showed that wheat cultivars having high RWC are more resistant against drought stress.

\section{Acknowledgments}

The authors wish to express their gratitude to the Institute of Biological Production Systems, Leibniz Universität Hannover, Germany for the financial support and technical assistance granted for the realization of this work.

\section{References}

[1] Arjenaki, F. G., R. Jabbari1 and A. Morshedi, (2012). Evaluation of Drought Stress on Relative Water Content, Chlorophyll Content and Mineral Elements of Wheat (Triticum aestivum L.) Varieties. Intl J Agri Crop Sci. 11: 726-729.

[2] Blum, A. (1996). Crop response to drought and the intepretation of adaptation. Plant Growth Regulation, 20: 135-148.

[3] Blum, A., J. Zhang and H.T. Nguyen. (1999). Consistent differences among wheat cultivars in osmotic adjustment and their relationship to plant production. Field Crops Res., 64: 287-291.

[4] Chimenti, C.A., Marcantonio, M., Hall, A.J., (2006). Divergent selection for osmotic adjustment results in improved drought tolerance in maize (Zea mays L.) in both early growth and flowering phases. Field Crops Res. 95, 305-315.

[5] Dhanda, S.S. and D.S. Sethi. (1996). Genetics and interrelationships of grain yield and its related traits in bread wheat under irrigated and rainfed conditions. Wheat Inform. Service, 83: 19-27.

[6] Dichio, B., Xiloyannis, C., Sofo, A., Montanaro, G. (2005). Osmotic regulation in leaves and roots of olives trees during a water deficit and rewatering. Tree Physiol. 26, 179-185.

[7] El-Rawi, K. and A.M. Khalafalla. (1980). Design and analysis of agricultural experiments, El Mousel Univ., Iraq, 19.

[8] Farouk, S. (2011). Osmotic adjustment in wheat flag leaf in relation to flag leaf area and grain yield per plant. J. of Stress Physiology \& Biochemistry, Vol. 7 No. 2, pp. 117-138.

[9] Gaballah, M.S., B. Abou, H. Leila, A. El-Zeiny and S. Khalil, (2007). Estimating the performance of salt stressed sesame plant treated with antitranspirants. J. Applied Sci. Res., 3: 811-817.

[10] Golparvar, A.R. (2003). Genetic analysis of drought resistance in bread wheat cultivars. Ph. D Thesis, Islamic Azad Univ. Branch of Science and Res. of Tehran, pp: 287(In Persian).

[11] Golparvar, A.R. and A. Ghasemi-Pirbalouti and H. Madani. (2006). Genetic control of some physiological attributes in wheat under drought stress conditions. Pakistan J. of Biological Sciences 9 (8): 1442-1446.
[12] González A., I. Martín and L. Ayerbe (2008). Yield and Osmotic Adjustment Capacity of Barley Under Terminal Water-Stress Conditions. J. Agronomy \& Crop Science, Volume 194, Issue 2: 81-91.

[13] González, A. and L. Ayerbe (2011). Response of coleoptiles to water deficit: growth, turgor maintenance and osmotic adjustment in barley plants (Hordeum vulgare L.). Agricultural Sciences, 2: 159-166.

[14] Lazacano-Ferrat, I. and C. J. Lovat, (1999). Relationship between relative water content, nitrogen pools, and growth of Phaseolus vulgaris L. and P. acutifoolius A. Gray during water deficit. Crop. SCI., 39: 467-475.

[15] Ludlow MM, Muchow RC (1990) A critical evaluation of traits for improving crop yields in water limited environments. Advances in Agronomy 43: 107-153.

[16] Morgan, J.M. (1977 b). Differences in osmoregulation between wheat genotypes. Nature (London) 270: 234-235.

[17] Mayer, J. and G. Gozlan. (1982). Infraed thermal sensing of plant canopies a screening technique for dehydration avoidance in wheat. Field Crops Res., 5: 137-146.

[18] M Sinclair, T.R. and M.M. Ludlow, (1985). who taught plants thermodynamics? The unfulfilled potential of plant water potential Aust. J. Plant Physiol. 33: 213-217. M., Hare, R.A. and Fletcher, R.J., 1986. Genetic variation. J. Morgan, J.M., 1992 Agric. jjkkjkj.

[19] Morgan, J.M., Hare, R.A. and R.J Fletcher, (1986). Genetic variation in osmoregulation in bread and durum wheat and its relationship to grain yield in arrange of field environments. Aus. J. Agric. Res., 37: 449-457.

[20] Morgan, J.M., (1995). Growth and yield of wheat lines with differing osmoregulative capacity at high soil water deficit in seasons of varying evaporative demand. Field Crops Res. 40, 143152.

[21] Marcelis, L.F.M., Heuvelink, E., Goudriaan, J., (1998). Modelling biomass production and yield of horticultural crops: a review. Sci. Hort. 74, 83-111.

[22] Morgan, J.M. (1999). Pollen grain expression of a gene controlling differences in osmoregulation in wheat leaves: A simple breeding method. Aust. J. Agric. Res. 50: 953-962.

[23] Moinuddin, R. A. Fischer, K. D. Sayre, and M. P. Reynolds (2005). Osmotic Adjustment in Wheat in Relation to Grain Yield under Water Deficit Environments. Agron. J. 97: 1062-1071.

[24] Mart"ınez JP, Ledent JF, Bajji M, Kinet JM, Lutts S. (2003). Effect of water stress on growth, Nap and Kp accumulation and water use efficiency in relation to osmotic adjustment in two populations of Atriplex halimus. Plant Growth Regul, 41: 63-73.

[25] Mart"ınez JP, Ledent JF, Bajji M, Kinet JM, Lutts S. (2004). Is osmotic adjustment required for water stress resistance in the Mediterranean shrub Atriplex halimus L. J. of Plant Physiology 161: 1041-1051

[26] Martin M., F. Miceli, J. A. Morgan, M. Scalet and G. Zerbi (2009) Synthesis of Osmotically Active Substances in Winter Wheat Leaves as Related to Drought Resistance of Different Genotypes. J. of Agro. and Crop Science V. 171 Is. 3: 176-184.

[27] Passioura JB. (1996). Drought and drought tolerance. Plant Growth Regulation 20, 79-83.

[28] Passioura JB. (2007). The drought environment: physical, biological and agricultural perspectives. Journal of Experimental Botany 58, 113-117.

[29] Ramos, M.L.G., R. Parsons, J. I. Sprent and E. K. Games, (2003). Effect of water stress on nitrogen fixation and nodule structure of common bean. Pesq. Agropec. Brasilia., 38: 339-347.

[30] Schonfeld, M.A., R.C. Johnson, B.F. and Carwer, D.W. Mornhinweg, (1988). Water relations in winter wheat as drought resistance indicators. Crop. Sci., 28: 526-531.

[31] Snedecor, G.W. and W.G. Cochran. (1980). Statistical methods. 7th ed. Lowa State Unv. Press., Ames., Lowa, U.S.A.

[32] Siddique, M.R.B., A. Hamid and M.S. Islam. (2000). Drought stress effects on water relations of wheat. Bot. Bull. Acad. Sin., 41: 35-39.

[33] Suprunova T, Krugman T, Fahima T, Chrn G, Shams I, Korol A, Nevo E (2004) Differential expression of dehydrin genes in wild barley (Hordeum spontaneum), associated with resistance to water deficit. Plant Cell Environ. 27: 1297-1308.

[34] Slafer, G.A. and J.L. Araus. (1998). Improving wheat responses to abiotic stresses. In: Proceedings 9th International Wheat Genetic Symposium. Saskatoon, Canada, 1: 201-213. 
[35] Tahara, M., B. F. Carver, R. C. Johnson and E.L. Smith. (1990) Relationship between relative water content during reproductive development and winter wheat grain yield. Euphytica, 49: 255-262.

[36] Walker, T.T. (1960). The use of a selection index technique in the analysis of progeny row data. Emp. Cott. Gr. Rev. 37: 81-107.
[37] Yamasaki, S. and L. R. Dillenburg, (1999). Measurements of leaf relative water content in araucaria angustifolia. R. Bras. Fisiol. Veg., 11 (2): 69-75 